\title{
Generation of transgenic fibroblasts producing doxycycline-inducible human interferon- $\alpha$ or erythropoietin for a bovine mammary bioreactor
}

\author{
HEE YOUNG KANG ${ }^{1}$, EUI-JU HONG ${ }^{1}$, KYU-CHAN HWANG ${ }^{2}$, \\ NAM-HYUNG KIM ${ }^{3}$, WOO-SUK HWANG ${ }^{2}$ and EUI-BAE JEUNG ${ }^{1}$
}

${ }^{1}$ Laboratory of Veterinary Biochemistry and Molecular Biology, College of Veterinary Medicine, Chungbuk National University, Cheongju, Chungbuk 361-763; ${ }^{2}$ Department of Research and Development, Sooam Biotech Research Foundation, Seoul 137-851; ${ }^{3}$ Department of Animal Sciences, Chungbuk National University, Cheongju, Chungbuk 361-763, Republic of Korea

Received May 7, 2014; Accepted January 21, 2015

DOI: $10.3892 / \mathrm{mmr} .2015 .3483$

\begin{abstract}
Interferon $\alpha(\operatorname{IFN}-\alpha)$ is a cytokine, produced predominantly in immune cells in response to pathogens, which interferes with viral replication in host cells. Another cytokine hormone, erythropoietin (EPO), is synthesized in interstitial fibroblasts of the kidney and acts as a stimulator for the production of red blood cells. Importantly, the two cytokines have been used in the treatment of certain hematological malignancies, including renal anemia. In the production of recombinant proteins, a transgenic expression system in bovine species is an efficient strategy for pharmaceutical production. In the present study, recombinant constructs capable of producing recombinant human IFN- $\alpha$ and EPO proteins were established and were generated containing the mammary gland-specific $\alpha \mathrm{S} 1$-casein promoter region (between -175 and $+796 \mathrm{nt}$ ), as this promoter was revealed to have the highest level of activity in a previous promoter study. In order to minimize developmental toxicity by constitutive exogenous expression, a doxycycline (dox)-inducible system was introduced to the IFN- $\alpha /$ EPO-expressing constructs. Therefore, a unitary tetracycline (tet)-on the IFN- $\alpha /$ EPO vector was established, which combined a tet-on activator cassette controlled by the $\alpha \mathrm{S} 1$-casein promoter, with a responder cassette encoding the
\end{abstract}

Correspondence to: Dr Eui-Bae Jeung, Laboratory of Veterinary Biochemistry and Molecular Biology, College of Veterinary Medicine, Chungbuk National University, 1 Chungdae-ro, Seowon-gu, Cheongju, Chungbuk 361-763, Republic of Korea E-mail: ebjeung@chungbuk.ac.kr

Dr Woo-Suk Hwang, Department of Research and Development, Sooam Biotech Research Foundation, 64 Kyungin-ro, Guro-gu, Seoul 137-851, Republic of Korea

E-mail: hwangws@sooam.org

Key words: fibroblast, interferon- $\alpha$, erythropoietin, bioreactor, doxycycline, bovine
IFN- $\alpha /$ EPO gene, controlled by the tetracycline response element (TRE) promoter. In these systems, the tet-controlled transactivator is affected by mammary gland-specific $\alpha \mathrm{S} 1$-casein promoter, and binding of the transcriptional activator to the TRE results in transcription of the downstream IFN- $\alpha /$ EPO genes in the presence of dox. To assess this, the unitary tet-on IFN- $\alpha / \mathrm{EPO}$ vector was introduced into a bovine mammary gland cell line (MAC-T), and the cells were then treated with $0.1-1 \mu \mathrm{g} / \mathrm{ml}$ dox. A marked increase was observed in the expression levels of IFN- $\alpha / E P O$. In addition, bovine transgenic fibroblasts containing a mammary gland-specific and dox-inducible IFN- $\alpha /$ EPO construct were generated. These transgenic fibroblasts may provide a source for somatic cell nuclear transfer for the generation of transgenic cattle producing recombinant human IFN- $\alpha /$ EPO protein during lactation.

\section{Introduction}

Interferons (IFNs) are glycoproteins produced by the immune system of host cells in response to infection of pathogens (1-4). Various forms of interferons have been evaluated as potential therapeutics in a number of solid tumors and hematological malignancies, including renal anemia, renal cell carcinoma, melanoma, acquired immune deficiency syndrome-associated Kaposi's sarcoma, follicular lymphoma, hairy cell leukemia and chronic myelogenous leukemia (1). INF- $\alpha$ and INF- $\beta$ cytokines exert their antiviral function by eliciting antiviral activity from target cells and inducing apoptosis in infected cells. They also contribute to the immune response by activation of natural killer cells and macrophages (2-4). IFN- $\alpha$ was approved by the Food and Drug Administration as a treatment for hairy cell leukemia in 1986 (1) and, using a gene cloning method, pure IFN has been used in clinical investigations (1).

Erythropoietin (EPO) is an acidic glycoprotein hormone with a molecular weight of 30-34 $\mathrm{kDa}$. This protein comprises 165 amino acids and contains multiple isoforms, which differ in their carbohydrate structure (5). EPO is expressed in the liver during the fetal stages. Following birth, it is 
predominantly synthesized in the peritubular fibroblasts of the renal cortex (6). Under hypoxic conditions, EPO is elevated in the plasma, and the induced EPO then stimulates the synthesis of more red blood cells in the bone marrow and increases the oxygen-carrying capacity of the blood $(6,7)$. The expression levels of EPO are inversely correlated with levels of hematocrit and hemoglobin, and reflect the reciprocal association between oxygen supply and EPO synthesis (8). EPO deficiency is the main cause of anemia in patients with chronic kidney disease (CKD) and contributes to anemia in patients with chronic inflammation and cancer (8). According to a previous study, anemia in patients with CKD or cancer may be effectively corrected by treatment with recombinant EPO (9).

As cytokines, IFN- $\alpha$ and EPO have been used in the treatment of certain hematological malignancies, including renal anemia $(1,8)$. Therefore, the production of pharmaceutical recombinant human IFN- $\alpha$ and EPO is of value. Importantly, these recombinant proteins require activation through posttranslational modification (PTM) for purification and therapeutic use (10). Due to the absence of appropriate mechanisms for the PTM of exogenous protein in prokaryotic cells, the production of recombinant proteins using a prokaryotic cell culture system is less effective compared with that of recombinant proteins using transgenic animals (11), which are termed bioreactors expressing a transgene. Milk-producing animals, including cattle, goats and sheep, are the optimal bioreactors as they produce large quantities of a recombinant protein in their mammary glands $(10,12,13)$.

Using a promoter of milk-specific proteins, including caseins and whey acidic proteins, numerous research groups have generated various recombinant proteins (14-17). In bovine milk, the quantity of $\alpha \mathrm{S} 1-, \alpha \mathrm{S} 2-, \beta$ - and $\kappa$-casein, $\alpha$-lactalbumin and $\beta$-lactoglobulin comprises $\sim 90 \%$ of the proteins (18). The expression and secretion of milk proteins in the mammary gland is regulated through interactions between particular hormone-activated transcription factors by steroid and peptide hormones, including insulin, prolactin and hydrocortisone $(19,20)$. Promoters of the casein gene have binding sites for transcription factors, including the glucocorticoid receptor and the transcriptional activator (TA) CCAAT/enhancer binding protein (21-24).

The unregulated expression of a target gene often produces unexpected results through a constitutively active promoter; for instance, overproduction of EPO results in erythrocytosis (25). As excess production of transgene can cause stillbirths and spontaneous abortions in animal bioreactors, a conditional transgenic technique, the tetracycline (tet)-on system, was used in the present study for establishment of fibroblasts with transgenes expressing mammary gland-specific human IFN- $\alpha$ or EPO. This system enables temporal and spatial regulation of transgene expression and requires a responder construct and activator construct in a single cell (26). The activator construct consists of a cytomegalovirus (CMV) promoter and TA, which induces conformational change by tet or its analog, doxycycline (dox) (27). The responder construct contains the target gene and ZsGreen 1 cDNA, controlled by the TA-response element promoter. In the presence of dox, conformationally changed TA binds to the tetracycline response element (TRE) promoter of the responder construct. Finally, a series of these processes induces the transcription of the target gene and a green fluorescent protein reporter gene, as an indicator of expression (28).

In the present study, a unitary vector system was established, combining an activator cassette with a responder cassette. The CMV promoter of the activator cassette was exchanged for the bovine $\alpha \mathrm{S} 1$-casein promoter, as the mammary tissue-specific promoter. In addition, bovine transgenic fibroblasts were generated containing a mammary gland-specific, dox-inducible human IFN- $\alpha$ or EPO gene. These cells can be utilized as a source of somatic cell nuclear transfer (SCNT) for the generation of animal bioreactors, which produce large quantities of human IFN- $\alpha$ or EPO protein in their milk.

\section{Materials and methods}

Animal care and ethics statement. Cattle were fed a standard commercial cow diet (Suwon Purina, Suwon, Korea) and provided with water ad libitum in accordance with the animal study guidelines of the Sooam Biotech Research Foundation for Accreditation for Laboratory Animal Care and Use. All surgery was performed under isoflurane anesthesia (3-5\%; Hana Pharm Co., Ltd., Seoul, South Korea), and all efforts were made to minimize suffering. The current study was approved by the ethics committee of Sooam Biotech Research Foundation (Seoul, South Korea).

Cell culture. The MAC-T bovine mammary epithelial cell line, was cultured in Dulbecco's modified Eagle's medium (DMEM; Gibco-BRL, Gaithersburg, MD, USA) containing $25 \mathrm{mM}$ glucose, supplemented with $10 \%$ fetal bovine serum (FBS; Welgene, Daejeon, South Korea), $100 \mathrm{U} / \mathrm{ml}$ penicillin and $100 \mu \mathrm{g} / \mathrm{ml}$ streptomycin (Welgene). Bovine fibroblasts were obtained from a bovine fetus (Deutsche Schwarzbunte) on day 30 of pregnancy through disaggregation by $0.05 \%$ trypsin (Welgene) treatment, and were maintained in DMEM containing $25 \mathrm{mM}$ glucose, supplemented with $10 \% \mathrm{FBS}$, $100 \mathrm{U} / \mathrm{ml}$ penicillin and $100 \mu \mathrm{g} / \mathrm{ml}$ streptomycin. All the cells were grown in a humidified $5 \% \mathrm{CO}_{2}$ atmosphere at $37^{\circ} \mathrm{C}$.

Vector construction. All restriction enzymes were obtained from Takara Bio, Inc. The $\alpha \mathrm{S} 1$-casein promoter region between nucleotides -175 and +796 demonstrated the highest transcriptional activity in a previous study (29) and were prepared by long-range PCR using the genomic DNA of bovine fibroblasts as the template and specific primers containing restriction enzyme sites (SpeI at the 5' end or SacII at the 3' end), using an identical procedure to that described above. The amplified fragments were digested using SpeI and SacII and replaced with the CMV promoter of the TA plasmid, pCMV-Tet3 G, purchased from Clontech (Mountain View, CA, USA). The human IFN- $\alpha$ or EPO cDNA was prepared via PCR using cDNA amplified from total human RNA (Clontech) as a template and was inserted into pTRE3G-ZsGreen1, which contained the ZsGreen1 green fluorescence protein (Clontech), through either MluI at the 5' end or BamHI at the 3' end. The human IFN- $\alpha$ or EPO expressing tTA-response region, obtained from the recombinant pTRE3G-ZsGreen1-human IFN- $\alpha /$ EPO construct by PCR, was then digested with either Bst1107I or SpeI and combined with the recombinant paS1P-Tet3 G vector, controlled by the bovine $\alpha$ S1-casein promoter. 
Table I. Primer sequences for reverse transcription polymerase chain reaction.

\begin{tabular}{|c|c|c|c|}
\hline Primer & $\begin{array}{c}\text { Restriction } \\
\text { enzyme }\end{array}$ & Direction & Sequence $\left(5^{\prime}-3^{\prime}\right)$ \\
\hline$\alpha \mathrm{S} 1$-casein promoter $(-175 \mathrm{nt})$ & SpeI & Forward & GGGACTAGTTAGAACAATGCCATTCCATTTCC \\
\hline$\alpha \mathrm{S} 1$-casein promoter $(+796 \mathrm{nt})$ & SacII & Reverse & CCGCGGTGTGCTGGAAAAATGCGTTT \\
\hline hIFN- $\alpha$ & $M l u \mathrm{I}$ & Forward & ACGCGTATGGCCTTGACCTTTGCTTTA \\
\hline hIFN- $\alpha$ & BamHI & Reverse & CCCGGATCCTCATTCCTTACTTCTTAAАCTTTCT \\
\hline hEPO & MluI & Forward & ACGCGTATG GGGGTGCACGAATGTCC \\
\hline hEPO & BamHI & Reverse & GGATCCTCATCTGTCCCCTGTCCTGCA GG \\
\hline Tet-response element & BstZ17I & Forward & GTATACCGAGGCCCTTTCGTCTTCAAGAATTC \\
\hline Tet-response element & SpeI & Reverse & ACTAGTGCCGCAGACATGATAAGATACATTGA \\
\hline Confirming primer a & - & Forward & TAGAACAATGCCATTCCATTTCC \\
\hline Confirming primer a' & - & Reverse & TTTCAGAAGTGGGGGCATAG \\
\hline Confirming primer $\mathrm{b}$ & - & Forward & GAGGATGGAGCAGTTTGCAT \\
\hline Confirming primer $\mathrm{b}^{\prime}$ & - & Reverse & GCATTCCACCACTGCTCCCA \\
\hline Bovine GAPDH & - & Forward & GGGTCATCATCTCTGCACCT \\
\hline Bovine GAPDH & - & Reverse & GGTCATAAGTCCCTCCACGA \\
\hline hIFN- $\alpha$ & - & Forward & TCCAAAAGGCTGAAACCATC \\
\hline hIFN- $\alpha$ & - & Reverse & CAGGCACAAGGGCTGTATTT \\
\hline hEPO & - & Forward & TCACTGTCCCAGACACCAAA \\
\hline hEPO & - & Reverse & CACTGACGGCTTTATCCACA \\
\hline
\end{tabular}

hIFN- $\alpha$, human interferon $\alpha$; hEPO, human erythropoietin.

Establishment of transgenic cell lines. The fibroblasts were transfected with the linearized targeting vector using Lipofectamine 2000 (Invitrogen Life Technologies, Carlsbad, CA, USA) according to the manufacturer's instruction and incubated for $4 \mathrm{~h}$ in a humidified $\mathrm{CO}_{2}$ atmosphere at $37^{\circ} \mathrm{C}$, then the media was replaced with fresh complete media (DMEM with $10 \%$ FBS and antibiotics). After one day, the medium was replaced with DMEM supplemented with $10 \%$ FBS, antibiotics and $500 \mu \mathrm{g} / \mathrm{ml} \mathrm{G}-418$ (Roche) for 4 weeks. The antibiotic-resistant cells were further selected using PCR-based genotyping (cycling conditions: Denaturation at $95^{\circ} \mathrm{C}$ for $30 \mathrm{sec}$, annealing at $62^{\circ} \mathrm{C}$ for $30 \mathrm{sec}$ and 30 cycles of extension at $72^{\circ} \mathrm{C}$ for $2 \mathrm{~min}$ ) with confirming primers (Table I) to identify the integration of target genes into the genomic DNA of bovine fibroblasts.

Genomic DNA extraction and polymerase chain reaction $(P C R)$. Genomic DNA from the cells was isolated using a G-DEX ${ }^{\mathrm{TM}}$ IIc genomic DNA extraction kit (iNtRON Biotechnology, Seoul, South Korea). Genomic DNA $(0.1 \mu \mathrm{g})$ was amplified in a $20 \mu \mathrm{l}$ PCR reaction containing $1 \mathrm{U}$ i-Start Taq polymerase (iNtRON Biotechnology), 2 mM dNTPs (Takara Bio Inc., Otsu, Japan) and 10 pmol of each specific primer (Macrogene, Inc., Seoul, South Korea). The details of all the primers are presented in Table I. The PCR reactions were as follows: Denaturation at $95^{\circ} \mathrm{C}$ for $30 \mathrm{sec}$, annealing at $62^{\circ} \mathrm{C}$ for $30 \mathrm{sec}$, extension at $72^{\circ} \mathrm{C}$ for $2 \mathrm{~min}$ and 30 cycles of amplification were conducted. The PCR products were then subjected to cloning processes and/or separated on a $1 \%$ agarose gel (Roche, Indianapolis, IN, USA), stained with ethidium bromide (Amresco Inc., Solon, OH, USA) and images were captured and scanned under UV illumination using a Bio-Rad GelDoc EQ System (Bio-Rad Laboratories, Inc., Hercules, CA, USA).

Transient transfection and dox treatment. Transient transfection was performed using Lipofectamine ${ }^{\mathrm{TM}} 2000$ (Invitrogen Life Technologies), according to the manufacturer's instructions. Briefly, $1.2 \times 10^{5}$ cells were seeded in 6 -well tissue culture plates 1 day prior to transfection. In total, $4 \mu \mathrm{g}$ of the recombinant constructs was transfected into the cells in serum-free DMEM. Following incubation for $4 \mathrm{~h}$ at $37^{\circ} \mathrm{C}$, the medium was replaced with DMEM containing $10 \%$ FBS, $100 \mathrm{U} / \mathrm{ml}$ penicillin and $100 \mu \mathrm{g} / \mathrm{ml}$ streptomycin. Subsequently, various concentrations $(0,0.1$ and $1.0 \mu \mathrm{g} / \mathrm{ml})$ of dox were administered in transiently transfected cells for an additional $24 \mathrm{~h}$.

$R N A$ preparation and reverse transcription $(R T)-P C R$. The total RNA from the MAC-T cells was extracted using TRIzol reagent (Invitrogen Life Technologies), according to the manufacturer's instructions. The concentration of the total RNA was determined by measuring the absorbance at $260 \mathrm{~nm}$ using an Epoch ${ }^{\mathrm{TM}}$ Multi-Volume Spectrophotometer System (BioTek, Inc., Winooski, VT, USA). First-strand cDNA was prepared by subjecting total RNA $(1 \mu \mathrm{g})$ to RT using Moloney murine leukemia virus reverse transcriptase (Invitrogen Life Technologies) and random primers (9-mers; Takara Bio, Inc.). To determine the optimal conditions for logarithmic phase PCR amplification for target cDNA, aliquots of total cDNA $(1 \mu \mathrm{g})$ were amplified using different numbers of cycles. The bovine GAPDH gene was amplified as the internal control 
Table II. Transfection efficiencies of the porcine fibroblasts.

\begin{tabular}{lccr}
\hline Cell line & Trials (n) & G418-resistant colony (n) & PCR-positive colony (n) \\
\hline Recombinant hIFN- $\alpha$ & 2 & 29 & 5 \\
Recombinant hEPO & 2 & 28 & 12 \\
\hline
\end{tabular}

hIFN- $\alpha$, human interferon $\alpha$; hEPO, human erythropoietin; PCR, polymerase chain reaction.

A
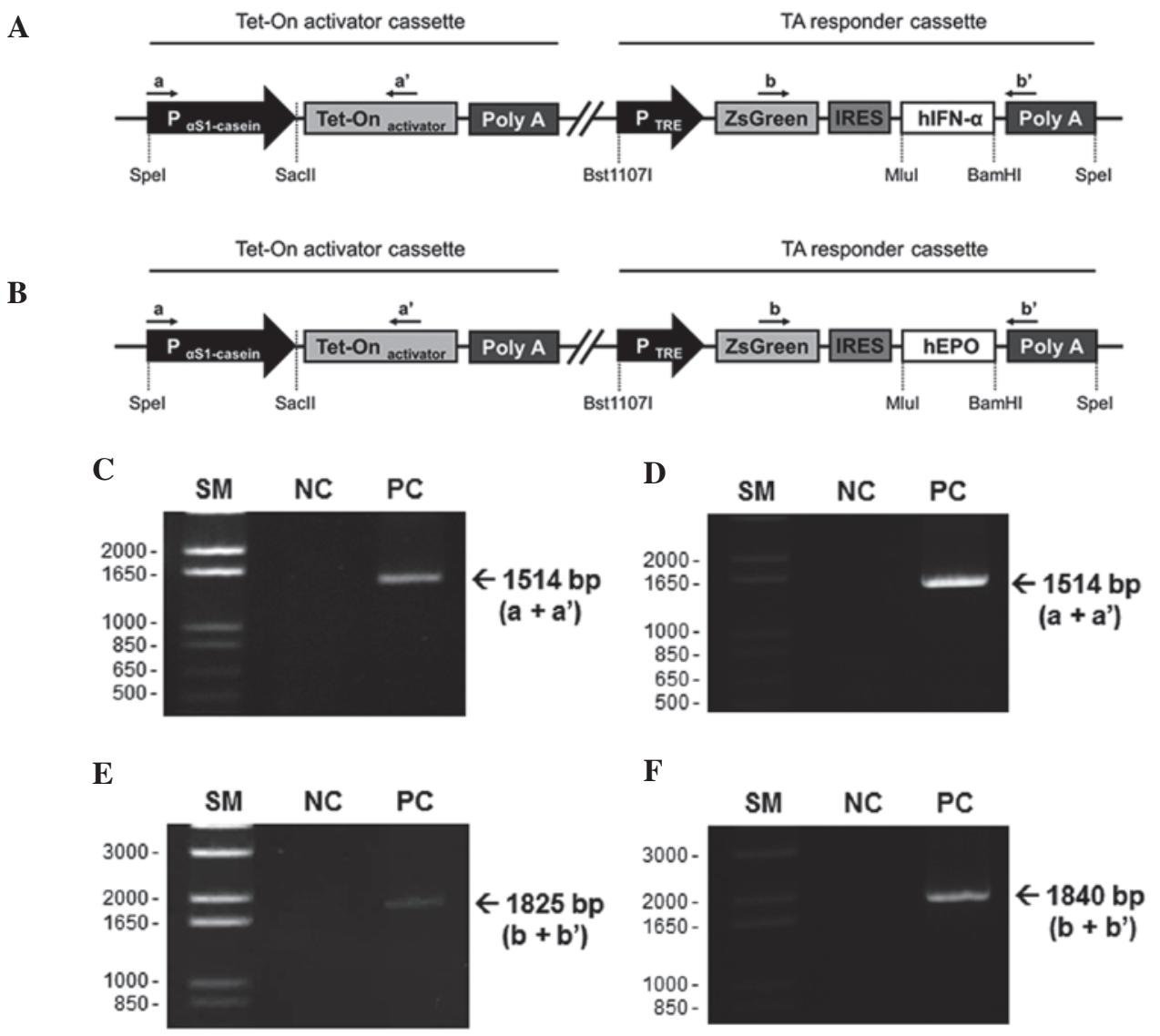

Figure 1. Schematic structure of the targeting vector and PCR-based confirmation of transgenic fibroblasts. The unitary tet-on system was composed of two regions in a vector; an activator cassette and a responder cassette. The activator cassette has tet-controlled TA under the control of the bovine $\alpha$ S1-casein promoter (between -175 and $+796 \mathrm{nt}$ ). The responder cassette contained the target gene, (A) human IFN- $\alpha$ or (B) EPO, and ZsGreen1 cDNA, expressing green fluorescence protein, controlled by the TA-response element promoter. These unitary vectors were linearized and integrated into the genomic DNA of the bovine fibroblasts. Genomic sDNA was isolated from the G418-resistant fibroblast colonies and was identified using specific primer sets (a, a', b and b'; Table I). (C and D) PCR products using primer a and a' indicated the chromosomal insertion of the activator cassette. (E and F) primers b and $b^{\prime}$ were used to confirm whether the same fibroblast colonies had the responder cassette (IFN $\alpha, 1825$ bp; EPO, 1840 bp). IRES, internal ribosomal entry site; SM, size marker; NC, negative control; PC, positive clone; PCR, polymerase chain reaction; EPO, erythropoietin; TA, tet-on transcriptional activator; IFN, interferon.

to rule out the possibility of RNA degradation and to control for variations in mRNA concentrations. A linear association between the PCR product band visibility and the number of amplification cycles was observed for the target mRNA. The bovine GAPDH gene and target genes were quantified using 25 and 30 cycles, respectively. The PCR reactions were denatured at $94^{\circ} \mathrm{C}$ for $30 \mathrm{sec}$, annealed at $58^{\circ} \mathrm{C}$ for $30 \mathrm{sec}$, and extended at $72^{\circ} \mathrm{C}$ for $30 \mathrm{sec}$. The PCR products were then separated on a $2.3 \%$ agarose gel and stained with ethidium bromide. Images were then captured under UV illumination and the images were scanned using GelDoc EQ (Bio-Rad Laboratories, Inc.).

\section{Results}

Establishment of a unitary tet-on IFN- $\alpha / E P O$ expression vector with a milk protein gene promoter. The constructed unitary tet-on system was composed of the activator cassette and the responder cassette (Fig. 1A and B). The activator cassette contained a TA under the control of the bovine $\alpha \mathrm{S} 1$-casein promoter (between -175 and $+796 \mathrm{nt}$ ), which demonstrated the highest promoter activity in a bovine MAC-T cell line in our previous study. The responder cassette was composed of either the human IFN- $\alpha$ or EPO gene, and linked with a gene for ZsGreen1 green fluorescence protein. Following transcription of the TA in mammary 


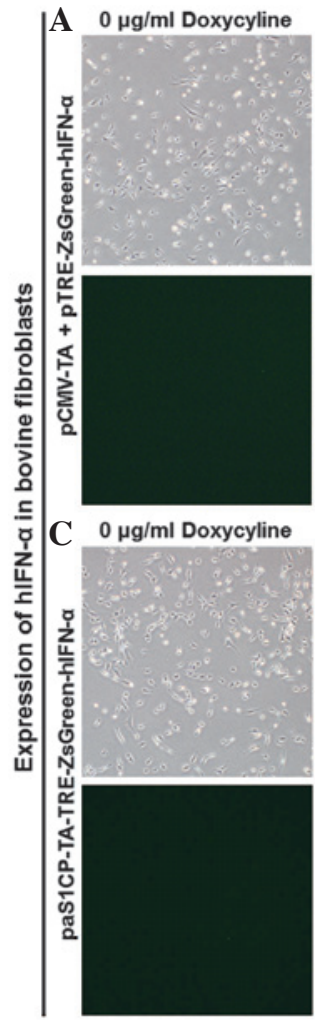

$0.1 \mu \mathrm{g} / \mathrm{ml}$ Doxycyline $1 \mu \mathrm{g} / \mathrm{ml}$ Doxycyline

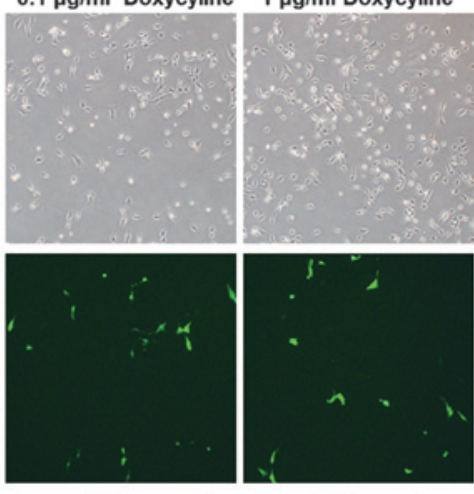

$0.1 \mu \mathrm{g} / \mathrm{ml}$ Doxycyline $1 \mu \mathrm{g} / \mathrm{ml}$ Doxycyline
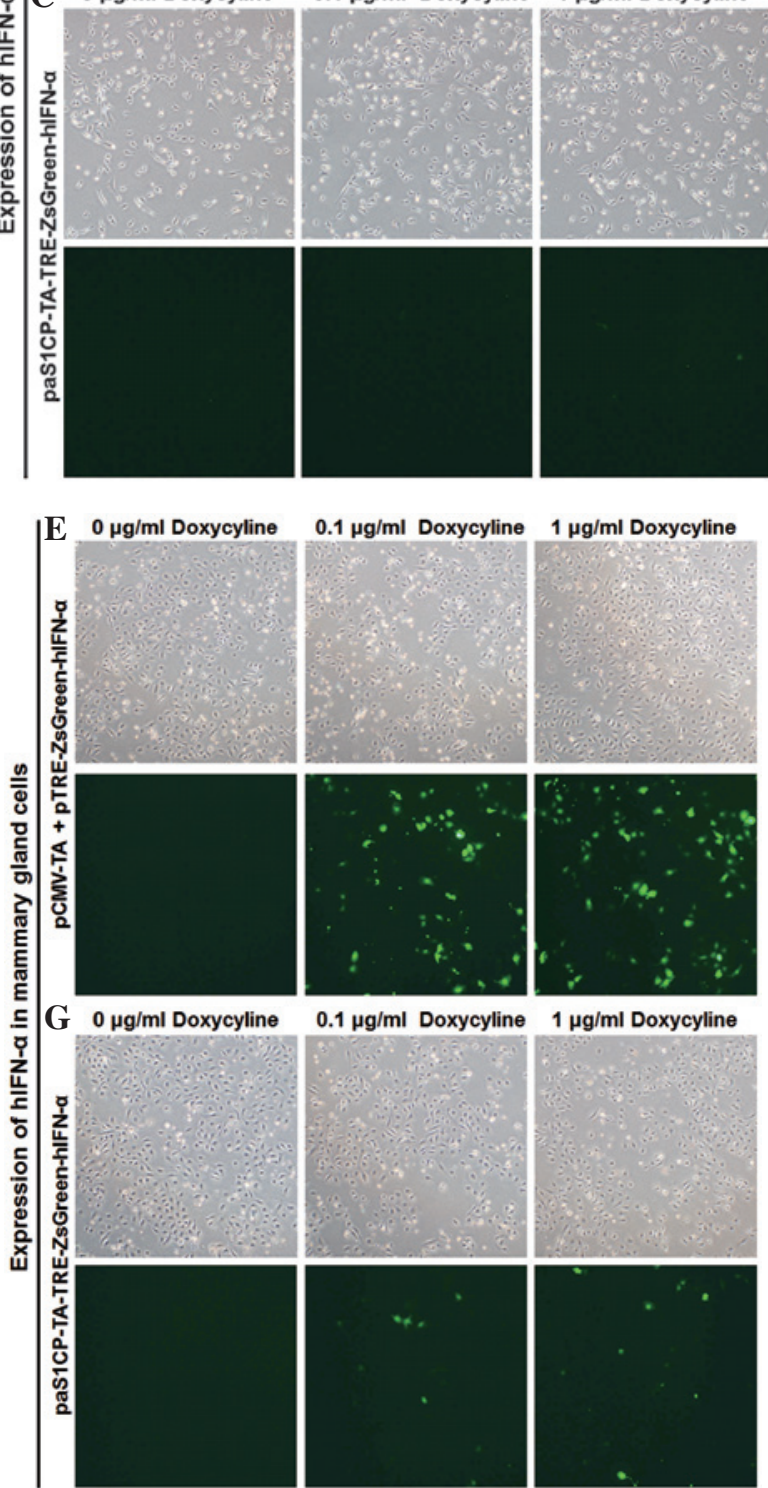

$0.1 \mu \mathrm{g} / \mathrm{ml}$ Doxycyline $1 \mu \mathrm{g} / \mathrm{ml}$ Doxycyline

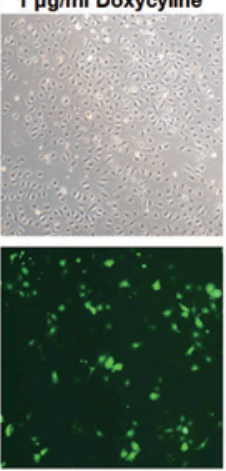

$0.1 \mu \mathrm{g} / \mathrm{ml}$ Doxycyline $1 \mu \mathrm{g} / \mathrm{ml}$ Doxycyline
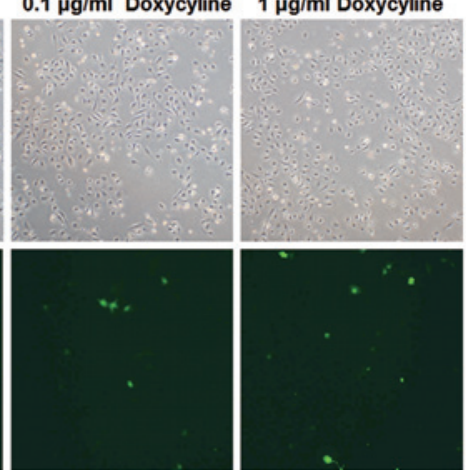

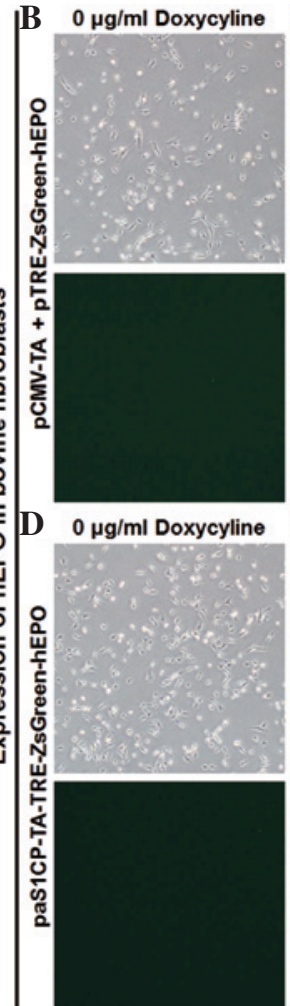

$0.1 \mu \mathrm{g} / \mathrm{ml}$ Doxycyline

$1 \mu \mathrm{g} / \mathrm{ml}$ Doxycyline
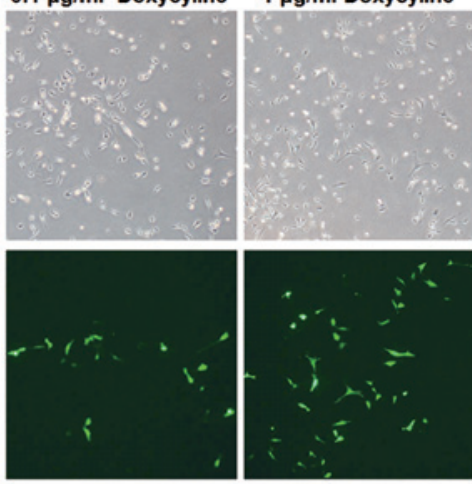

$0.1 \mu \mathrm{g} / \mathrm{ml}$ Doxycyline

$1 \mu \mathrm{g} / \mathrm{ml}$ Doxycyline
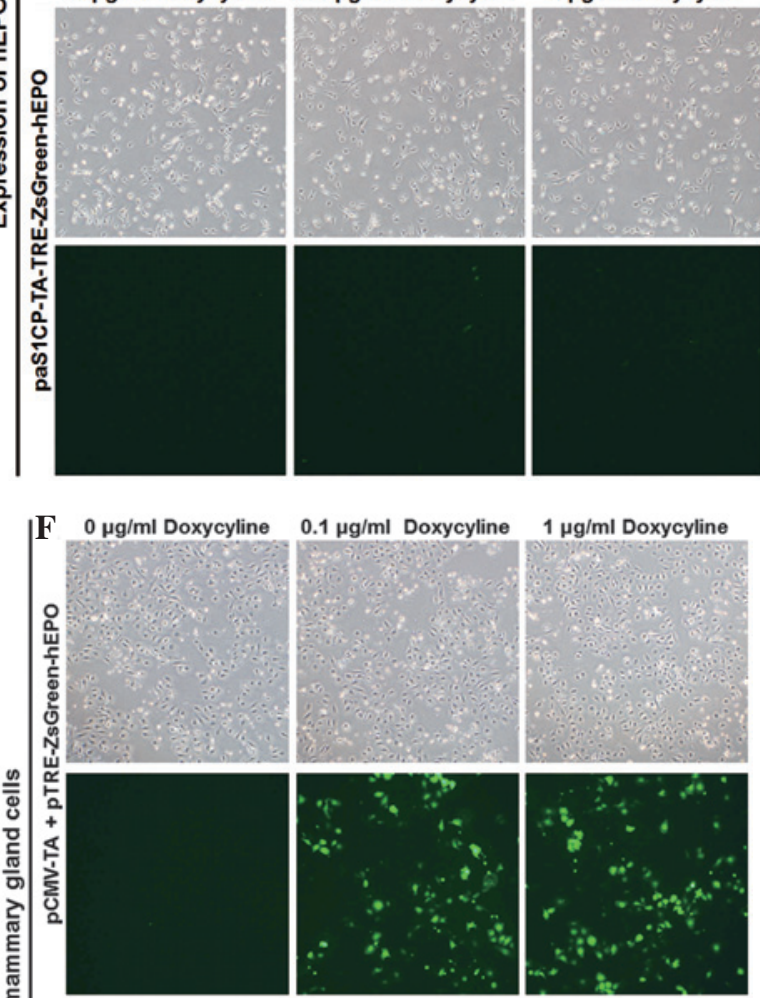

$0.1 \mu \mathrm{g} / \mathrm{ml}$ Doxycyline

$1 \mu \mathrm{g} / \mathrm{ml}$ Doxycyline
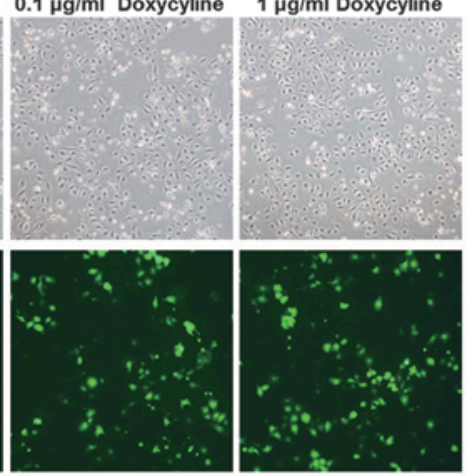

H $0 \mu \mathrm{g} / \mathrm{ml}$ Doxycyline

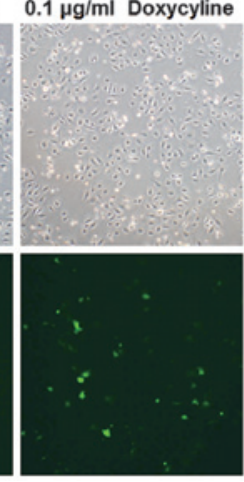

$0.1 \mu \mathrm{g} / \mathrm{ml}$ Doxycyline
$1 \mu \mathrm{g} / \mathrm{ml}$ Doxycyline

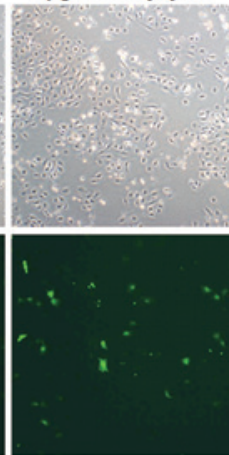

Figure 2. Observation of dox-inducible green fluorescence in the (A-D) bovine fibroblasts and (E-H) MAC-T cells using transient transfection of (A, B, E and F) pCMV-TA with pTRE-ZsGreen-IFN- $\alpha$ /EPO or (C, D, G and H) unitary paS1CP-TA-TRE-ZsGreen-IFN- $\alpha /$ EPO (magnification, X40). The Dox concentration was increased between $0,0.1$ and $1 \mu \mathrm{g} / \mathrm{ml}$. In the MAC-T cells, dox-inducible and mammary gland specific expression of green fluorescence by bovine $\alpha 1 \mathrm{~S}$ casein promoter was observed. Additionally, the green fluorescence revealed a dose-dependent increase in expression as the dox concentration increased between $0,0.1$ and $1 \mu \mathrm{g} / \mathrm{ml}$. Image were captured using a bright field microscope and are representative of the cell density and degree of fluorescent to non-fluorescent cells. CMV, cytomegalovirus promoter; TA, tet-on transcription activator; $\alpha$ S1CP, bovine $\alpha 1 \mathrm{~S}$ casein promoter; EPO, erythropoietin; IFN- $\alpha$, interferon- $\alpha$; Dox, doxycycline; MAC-T, mammary epithelial cell line.

gland cells by tissue-specific activity of the bovine $\alpha$ S1-casein promoter, it binds to the TRE promoter of the responder cassette following conformational change by dox (26-28). In this system, the human IFN- $\alpha / \mathrm{EPO}$ was specifically expressed in mammary tissue and expression of the ZsGreen1 green fluorescence marker was observed in the presence of dox. 


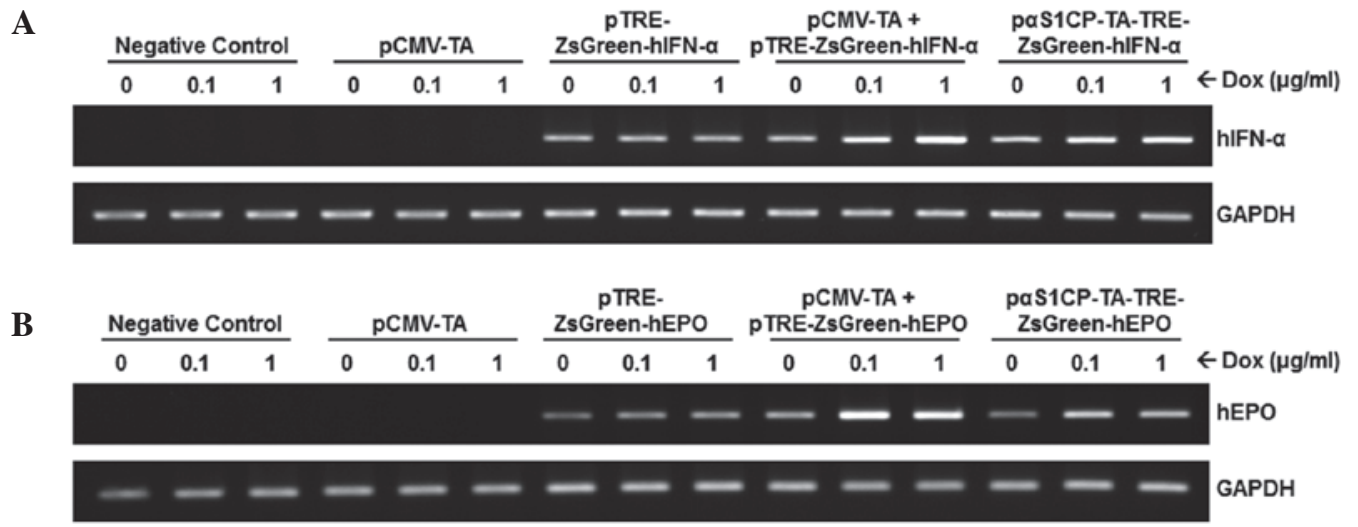

Figure 3. Dox-inducible mRNA expression of human (A) IFN- $\alpha$ or (B) EPO in the MAC-T cells. Dox-dose dependent mRNA overexpression of IFN- $\alpha$ or EPO

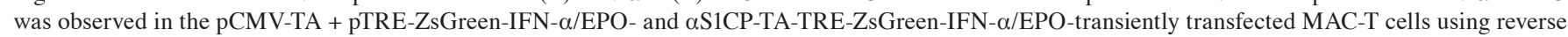
transcription-polymerase chain reaction. EPO, erythropoietin; IFN- $\alpha$, interferon- $\alpha$; Dox, doxycycline.

Generation of fibroblast cell lines expressing the dox-inducible human IFN- $\alpha / E P O$ protein. The dox-inducible human IFN- $\alpha /$ EPO construct was digested and linearized using $B s t 1107$ I. These constructs were introduced into bovine fibroblasts using a liposomal-mediated gene delivery system. The transfected fibroblasts were maintained in medium containing G418 (500 $\mu \mathrm{g} / \mathrm{ml})$ for four weeks, and the G418-resistant and stably cloned fibroblasts were selected. To confirm chromosomal integration of the targeting vector, PCR was performed using primer sets specific for the vector (Table I). The selected clones were amplified using a and a' primers (product size, 1,514 bp; Fig. 1C and D). The genomic DNA extracted from the clones expressing human IFN- $\alpha$ was analyzed using $\mathrm{b}$ and b' primers (product size, 1,825 bp; Fig. 1E). In addition, genomic DNA obtained from clones expressing human EPO was evaluated using $\mathrm{b}$ and $\mathrm{b}$ ' primers (product size, 1,840 bp; Fig. 1F). Based on the results of the gene cloning, five positive clones from the $29 \mathrm{G} 418$-resistant and IFN- $\alpha$-transfected clones, and 12 positive clones from the 28 G418-resistant and EPO-transfected clones were obtained in the two rounds of transfection, respectively (Table II). The fibroblasts from the positive clones may serve as a cell source for SCNT for the generation of a bovine bioreactor to produce recombinant human IFN- $\alpha$ or EPO in its milk.

Observation of dox-inducible fluorescence in MAC-T cells and bovine fetal fibroblasts. For the observation of tissue-specific expression, transient transfection was performed in the MAC-T bovine mammary epithelial cell line and bovine fibroblasts. These cells were cotransfected with pCMV-TA and pTRE-ZsGreen1-IFN- $\alpha /$ EPO constructs as a positive control to confirm the activity of the dox-inducible expression system. No fluorescence was observed in either the untreated or dox-treated bovine fetal fibroblasts transiently transfected with $\alpha \alpha$ S1CP-TA-TRE-ZsGreen-IFN $\alpha /$ EPO as a result of the mammary gland specific casein promoter (Fig. 2A-D). However, in the MAC-T cells expressing p $\alpha$ S1CP-TA-TRE-ZsGreen-IFN $\alpha / E P O$, green fluorescence was observed, indicating the expression of dox-inducible and mammary gland-specific IFN- $\alpha /$ EPO (Fig. 2E-H). Green fluorescence was also confirmed following dox treatment in a dose-dependent manner $(0,0.1$, and $1 \mu \mathrm{g} / \mathrm{ml})$.
Dox-inducible mRNA expression of human IFNa/EPO in $M A C-T$ cells. To evaluate the dox-inducible expression of IFN $\alpha / E P O$ under the control of the $\alpha \mathrm{S} 1$ casein promoter, RT-PCR was performed using mRNA obtained from transiently transfected MAC-T cells and bovine fetal fibroblasts (data not shown). In parallel with the results observed in the fluorescence microscopy, dox-dose dependent and mammary gland-specific transcripts of IFN $\alpha /$ EPO were observed in the MAC-T cells (Fig. 3) following dox treatment, however, this was not observed in the bovine fibroblasts (data not shown). In addition, the expression of IFN $\alpha / E P O$ in cells transfected with pCMV-TA or pTRE-ZsGreen1-IFN $\alpha / E P O$ exhibited no notable changes with or without dox. Although the expression of IFN $\alpha / \mathrm{EPO}$ in the MAC-T cells expressing the pTRE-ZsGreen1-IFN $\alpha / E P O$ transgene was observed, its level was consistently low and unaffected by dox treatment. Factors in the transcriptional environment, which remain to be elucidated, may control the gene expression in an in vitro system introducing the target gene.

\section{Discussion}

IFN is an important cytokine for immune responses against viral and bacterial infections and the mediation of anticancer activity either indirectly, through regulation of anti-inflammatory and anti-angiogenic responses, or directly, by affecting the proliferation and differentiation of cancer cells (30). IFN- $\alpha / \beta$ is known to be essential in the activation of natural killer cells and macrophages (2-4). As key cytokines, IFN- $\alpha / \beta$ links the innate and adaptive immune systems $(31,32)$. Another cytokine involved in the maintenance of red blood cell mass is EPO, which is involved in the proliferation and differentiation of erythrocytic progenitors (8). If plasma oxygen levels are low, EPO, which is released by the interstitial cells of the kidney, stimulates bone marrow to produce more red blood cells and increases the aerobic capacity of blood $(6,7)$.

IFN- $\alpha$ and EPO are glycoproteins, which are major therapeutic agents in the treatment of certain hematological malignancies, including chronic renal anemia and other diseases $(1,8)$. The mass production of these therapeutic agents is important in the pharmaceutical industry. Recombinant DNA technology has been widely used to obtain therapeutic agents 
in eukaryotic cell-based culture systems $(33,34)$. However, the productivity of these systems is limited in large-scale production. Although the productivity of a prokaryotic system is sufficient for the generation of recombinant proteins, the functional activity of recombinant proteins is restricted due to an absence of protein post-translational modification (11). Therefore, it was hypothesized that the generation of transgenic cattle, termed bioreactors, is a more effective method for the production of relatively large quantities of recombinant therapeutic agents. This technology using livestock has significant potential and economic merit in biomedicine, agriculture, human health industries and environmental sustainability $(35,36)$.

In the present study, bovine fibroblast cell lines expressing human IFN- $\alpha$ /EPO transgenes were developed in order to generate transgenic cattle. Milk is the easiest body fluid to obtain from ruminants (35). The capacity for mass-production of the mammary gland, coupled with the relative ease of harvesting milk, means it is the organ of choice for the production of pharmaceutical products from animals. In our previous study, a $\alpha \mathrm{S} 1$-casein promoter region spanning between -175 and +796 nt was assessed, which demonstrated the highest expression activity among all the assessed promoters (29). Therefore, this promoter was applied in the present study for the generation of bovine transgenic fibroblasts containing dox-inducible human IFN- $\alpha$ and EPO genes, as a material for SCNT procedures in the production of an animal bioreactor.

IFN- $\alpha$ and EPO are useful therapeutic agents, As overexpression by constitutively active promoters may cause unexpected side effects, including erythrocytosis involved with the induction of EPO (25), a dox-inducible expression system was adopted in parallel with a tissue-specific promoter in the present study. The expression of mammary gland-specific and dox-inducible human IFN- $\alpha$ or EPO was observed in an MAC-T bovine mammary epithelial cell line, which is an immortalized epithelial cell line isolated from bovine mammary tissue (37). Mammary epithelial cells are the functional unit of the mammary gland. MAC-T cells provide a useful tool in the evaluation of foreign gene expression and the assessment of mammary tissue-specific expression in vitro, as they retain a number of biochemical and morphological characteristics of the mammary gland in vivo (38). The unitary tet-on IFN- $\alpha /$ EPO induction system has mammary gland-specific and dox-inducible traits. When generating animal bioreactors, these cellular traits may reduce rates of stillbirth during pregnancy and unwanted outcomes caused by uncontrollable gene expression.

For the generation of transgenic cattle, these transgenic fibroblasts may be used in SCNT, a method used to perform sequential genetic modifications, targeted DNA insertions and artificial chromosome transfer using long-term cultured somatic cells. The human IFN- $\alpha /$ EPO-transgenic fibroblasts established in the present study may be used for the generation of transgenic cattle using SCNT technology. In this process, the nucleus containing chromosomal DNA in an egg cell may be removed and replaced with a nucleus containing genetically modified chromosomal DNA obtained from the transgenic fibroblast. Fusion between the enucleated egg cell and the donor somatic nucleus creates a new cell, which gains a complete set of chromosomes derived from the donor nucleus. The SCNT method has several advantages in the genetic cloning of valuable transgenic animals. The production of live offspring by SCNT using adult skin fibroblast cells was reported in goats in 1999 (39) and in cattle in 2000 (40), demonstrating the potential for use in the agricultural and pharmaceutical industries. If the animal bioreactors in the present study are born, they may produce recombinant human IFN- $\alpha$ and EPO proteins in milk on a daily basis and serve as a promising model for the production of recombinant therapeutic agents.

\section{Acknowledgements}

The present study was supported by a grant from the Next-Generation BioGreen 21 Program (grant no.PJ00956301), Rural Development Administration, Republic of Korea.

\section{References}

1. Jonasch E and Haluska FG: Interferon in oncological practice: review of interferon biology, clinical applications and toxicities. Oncologist 6: 34-55, 2001

2. Belardelli F: Role of interferons and other cytokines in the regulation of the immune response. APMIS 103: 161-179, 1995.

3. Biron CA, Nguyen KB, Pien GC, Cousens LP and Salazar-Mather TP: Natural killer cells in antiviral defense: function and regulation by innate cytokines. Annu Rev Immunol 17: 189-220, 1999.

4. Bogdan C: The function of type I interferons in antimicrobial immunity. Curr Opin Immunol 12: 419-424, 2000.

5. Jelkmann W: Erythropoietin after a century of research: younger than ever. Eur J Haematol 78: 183-205, 2007.

6. Neumann E: Regulation of erythropoiesis. Acta Med Austriaca Supp 6: 360-363, 1979 (In German).

7. Argenti M: Hematosis and erythropoiesis in guinea pigs exposed to low oxygen pressure. Riv Med Aeronaut 14: 283-313, 1951 (In Undetermined Language).

8. Jelkmann W: Regulation of erythropoietin production. J Physiol 589: 1251-1258, 2011.

9. Macdougall IC and Ashenden M: Current and upcoming erythropoiesis-stimulating agents, iron products and other novel anemia medications. Adv Chronic Kidney Dis 16: 117-130, 2009.

10. Yang X and Carter MG: Transgenic animal bioreactors: a new line of defense against chemical weapons? Proc Natl Acad Sci USA 104: 13859-13860, 2007.

11. Baneyx F: Recombinant protein expression in Escherichia coli. Curr Opin Biotechnol 10: 411-421, 1999.

12. Ebert KM, Selgrath JP, DiTullio P, et al: Transgenic production of a variant of human tissue-type plasminogen activator in goat milk: generation of transgenic goats and analysis of expression. Biotechnology (N Y) 9: 835-838, 1991.

13. Krimpenfort P, Rademakers A, Eyestone W, et al: Generation of transgenic dairy cattle using 'in vitro' embryo production. Biotechnology (NY) 9: 844-847, 1991.

14. Buhler TA, Bruyere T, Went DF, Stranzinger G and Burki K: Rabbit beta-casein promoter directs secretion of human interleukin-2 into the milk of transgenic rabbits. Biotechnology (N Y) 8: 140-143, 1990.

15. Cerdan MG, Young JI, Zino E, et al: Accurate spatial and temporal transgene expression driven by a 3.8-kilobase promoter of the bovine beta-casein gene in the lactating mouse mammary gland. Mol Reprod Dev 49: 236-245, 1998.

16. Ebert KM, DiTullio P, Barry CA, et al: Induction of human tissue plasminogen activator in the mammary gland of transgenic goats. Biotechnology (N Y) 12: 699-702, 1994.

17. Gordon K, Lee E, Vitale JA, Smith AE, Westphal H and Hennighausen L: Production of human tissue plasminogen activator in transgenic mouse milk. 1987. Biotechnology 24: 425-428, 1992.

18. Ikonen T, Ojala M and Ruottinen O: Associations between milk protein polymorphism and first lactation milk production traits in Finnish Ayrshire Cows. J Dairy Sci 82: 1026-1033, 1999.

19. Buser AC, Gass-Handel EK, Wyszomierski SL, et al: Progesterone receptor repression of prolactin/signal transducer and activator of transcription 5-mediated transcription of the beta-casein gene in mammary epithelial cells. Mol Endocrinol 21: 106-125, 2007. 
20. Doppler W, Windegger M, Soratroi C, et al: Expression level-dependent contribution of glucocorticoid receptor domains for functional interaction with STAT5. Mol Cell Biol 21: 3266-3279, 2001.

21. Raught B,Liao WS and Rosen JM: Developmentally and hormonally regulated CCAAT/enhancer-binding protein isoforms influence beta-casein gene expression. Mol Endocrinol 9: 1223-1232, 1995.

22. Malewski T and Zwierzchowski L: Computer-aided analysis of potential transcription-factor binding sites in the rabbit beta-casein gene promoter. Biosystems 36: 109-119, 1995.

23. Rosen JM, Rodgers JR, Couch CH, et al: Multihormonal regulation of milk protein gene expression. Ann NY Acad Sci 478: 63-76, 1986.

24. Rosen JM, Wyszomierski SL and Hadsell D: Regulation of milk protein gene expression. Annu Rev Nutr 19: 407-436, 1999.

25. Hodges VM, Rainey S, Lappin TR and Maxwell AP: Pathophysiology of anemia and erythrocytosis. Crit Rev Oncol Hematol 64: 139-158, 2007.

26. Gossen $\mathrm{M}$ and Bujard $\mathrm{H}$ : Tight control of gene expression in mammalian cells by tetracycline-responsive promoters. Proc Natl Acad Sci USA 89: 5547-5551, 1992.

27. Zhou X, Vink M, Klaver B, Berkhout B and Das AT: Optimization of the Tet-On system for regulated gene expression through viral evolution. Gene Ther 13: 1382-1390, 2006

28. Gossen M, Freundlieb S, Bender G, Müller G, Hillen W and Bujard $\mathrm{H}$ : Transcriptional activation by tetracyclines in mammalian cells. Science 268: 1766-1769, 1995.

29. Jung EM, An BS, Kim YK, et al: Establishment of transgenic fibroblasts for producing recombinant human interferon- $\alpha$ and erythropoietin in bovine milk. Mol Med Rep 7: 406-412, 2013.

30. Wang CJ, Xiao CW, You TG, et al: Interferon-alpha enhances antitumor activities of oncolytic adenovirus-mediated IL-24 expression in hepatocellular carcinoma. Mol Cancer 11: 31, 2012.
31. Biron CA: Interferons alpha and beta as immune regulators - a new look. Immunity 14: 661-664, 2001.

32. Gallucci S, Lolkema M and Matzinger P: Natural adjuvants: endogenous activators of dendritic cells. Nat Med 5: 1249-1255, 1999.

33. Son YD, Jeong YT, Park SY and Kim JH: Enhanced sialylation of recombinant human erythropoietin in Chinese hamster ovary cells by combinatorial engineering of selected genes. Glycobiology 21: 1019-1028, 2011.

34. Tuite MF, Dobson MJ, Roberts NA, et al: Regulated high efficiency expression of human interferon-alpha in Saccharomyces cerevisiae. EMBO J 1: 603-608, 1982.

35. Wall RJ, Kerr DE and Bondioli KR: Transgenic dairy cattle: genetic engineering on a large scale. J Dairy Sci 80: 2213-2224, 1997.

36. Zuelke KA: Transgenic modification of cows milk for value-added processing. Reprod Fertil Dev 10: 671-676, 1998.

37. Huynh HT, Robitaille G and Turner JD: Establishment of bovine mammary epithelial cells (MAC-T): an in vitro model for bovine lactation. Exp Cell Res 197: 191-199, 1991.

38. Berry SD, Weber Nielsen MS, Sejrsen K, Pearson RE, Boyle PL and Akers RM: Use of an immortalized bovine mammary epithelial cell line (MAC-T) to measure the mitogenic activity of extracts from heifer mammary tissue: effects of nutrition and ovariectomy. Domest Anim Endocrinol 25: 245-253, 2003.

39. Baguisi A, Behboodi E, Melican DT, et al: Production of goats by somatic cell nuclear transfer. Nat Biotechnol 17: 456-461, 1999.

40. Kubota C, Yamakuchi H, Todoroki J, et al: Six cloned calves produced from adult fibroblast cells after long-term culture. Proc Natl Acad Sci USA 97: 990-995, 2000. 